Article

\title{
Comparative Review of Corporate Social Responsibility of Energy Utilities and Sustainable Energy Development Trends in the Baltic States
}

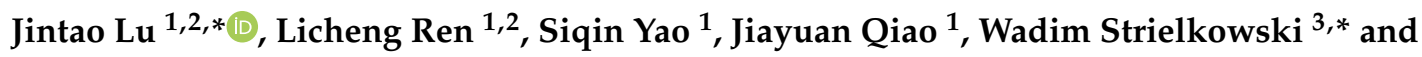 \\ Justas Streimikis ${ }^{4}$ \\ 1 Department of Business Administration, School of Economics and Management, Taiyuan University of \\ Science and Technology, Taiyuan 030024, China \\ 2 Research Center for Corporate Social Responsibility, Taiyuan University of Science and Technology, \\ Taiyuan 030024, China \\ 3 Department of Trade and Finance, Faculty of Economics and Management, Czech University of Life Sciences \\ Prague, 16500 Praha-Suchdol, The Czech Republic \\ 4 Lithuanian Institute of Agrarian Economics, 03105 Vilnius, Lithuania \\ * Correspondence: lut2002@163.com (L.J.); strielkowski@pef.czu.cz (W.S); Tel.: +86-351-277-6604 (L.J.); \\ $+42-060-350-8627$ (W.S.)
}

Received: 12 August 2019; Accepted: 2 September 2019; Published: 4 September 2019

\begin{abstract}
This paper aims at developing the theoretical framework for linking the CSR of energy utilities with sustainable energy development achievements and at applying this framework in selected countries. The main issues of CSR relevant to the energy sector are discussed, and a comparative analysis of CSR reports of energy utilities and sustainable energy development trends in the Baltic States (Lithuania, Latvia, and Estonia) is performed based on the developed framework. There are three main interlinked sustainable energy development targets: increase in energy efficiency, the use of renewable energy sources, and GHG emission reduction. The significance of CSR in the energy sector is underlined based on the literature review, and the state policies to promote CSR in the energy sector are discussed and critically assessed based on the case studies of three Baltic States. The CSR practices of energy utilities of the Baltic States were assessed and compared with sustainable energy development achievements in these countries, based on the analysis of sustainable energy development trends. Estonia achieved the best results in approaching all sustainable energy development targets and was ranked with the highest scores in CSR ranking among the Baltic States, followed by Lithuania. The results of the case studies demonstrate that the Baltic countries have achieved different results in sustainable energy development progress, and the role of energy utilities and their corporate sustainability practices may have huge impacts on the achievement of sustainable energy development targets.
\end{abstract}

Keywords: corporate social responsibility; energy utilities; sustainable energy development indicators; corporate social responsibility reports; Baltic States

\section{Introduction}

Many countries over the world are witnessing the major changes and adjustments caused by the recent trends of economic globalization and wide application of information technologies (ITs). They are experiencing rising instabilities and uncertainties and climate change, as well as other risks. In addition, one cannot but notice that countries across the globe are becoming increasingly interconnected and interdependent. Therefore, the most important global issues, such as instabilities and water and climate change risks, need to be dealt with unanimously by all countries. Political, 
economical, and environmental issues are increasingly becoming the responsibility of international business leaders as much as governments. Leading international corporations have already recognized the necessity for business to work in stable environments. However, the mounting inequality, poverty, and climate risks are frightening every business model. It is obvious that economic development and business initiatives cannot flourish in a situation of economic, social, and environmental unsteadiness. Tackling critical problems such as climate change, poverty, and gender inequality might benefit businesses by securing sustainable supply chains and markets for upcoming development. Corporate social responsibility (CSR) is the main business initiative helping to deal with the major risks.

With regard to the above, one has to mention the Belt and Road Initiative (BRI) which represents a global development strategy initiated by the Chinese government covering the development of infrastructure and rising investments in many countries around the world. The Belt and Road project currently includes 66 countries from all continents globally and aims at safeguarding world peace and stability by encouraging prosperity and sustainable development around the world [1]. Sustainable energy development and climate change mitigation are the key objectives of the BRI initiative. In addition, the European Union (EU) and China signed an agreement for the enhancement of the Paris Agreement implementation and decided to foster their cooperation on climate change, clean energy, and emissions trading.

The energy utilities industry has encountered many challenges linked to environmental and social issues during recent decades [2]. All of the mentioned risks, including environmental, health, and safety risks, are especially relevant to the long-term development of the energy sector. Thus, companies operating in the energy sector, especially public energy utilities, are expected to meet higher standards of performance, including social and environmental impacts [3].

Currently, energy utilities are experiencing important transformations, affecting all activities within the supply chain, from power generation to trading, including transmission and distribution [4]. The shift to renewable energy sources (RES) needs to be pursued in the electricity generation sector as well as heating and cooling, transport, and buildings, due to climate change risks. Some research shows that RES can provide four-fifths of the total power supply all over the world by 2050, enormously cutting GHG (greenhouse gas) emissions [5]. In addition, RES can accelerate the advancement of energy generation technologies. Therefore, companies operating in the energy sector can do a lot in fostering the penetration of renewables. Energy utilities play a crucial role in achieving sustainable energy development, and corporate social responsibility of energy utilities can provide, together with the increase in the usage of renewables, many external benefits for society [6].

There are only a few studies dealing with corporate social responsibility and CSR reporting practices of energy utilities in several countries: Brazil [7,8], Poland [9], The US [10,11], China [12,13], India, and Japan [14], as well as in some other countries [15-18]. However, most of those studies do not provide a clear understanding of linkages between corporate social responsibility and its implications for sustainable energy development. Some studies [19-22] dealt with corruption risk mitigation in the energy sector and CSR; however, they do not address the CSR impacts on sustainable energy development. Some studies analyzed CSR practices and their implications in other public sectors [23-27]. The majority of studies dealt with the CSR of public sector enterprises and their impacts in the water sector [28-35]. The main areas of investigation were the drivers of CSR [36-39], as well as the impacts of CSR practices on consumer perceptions and loyalty [40-50]. However, broader outcomes of the CSR of energy utilities were mainly undervalued and lacked serious attention.

There is a literature gap in analyzing the CSR of energy utilities and its implications for sustainable energy development in the country. This study aims at developing the theoretical framework for linking the CSR of energy utilities with sustainable energy development achievements and to apply this framework in transition countries having a decentralized energy sector. Although recent trends of restructuring, decentralization, and unbundling had some impact on the increase of the number of players in the energy market of transition economies, energy utilities are still dominating in the power sector. 
This paper proposes a theoretical framework for assessing the linkages between the corporate social responsibility of energy utilities and sustainable development of the energy sector. There are three main interlinked sustainable energy development targets: (i) increase in energy efficiency, (ii) usage of renewable energy sources, and (iii) GHG emission reduction. There are no other ways to reduce GHG emission from the energy sector as other decarbonization options like nuclear energy are not being considered as a sustainable energy option.

The model was empirically tested on the case study of the Baltic States. The CSR practices of energy utilities in three Baltic States were analyzed, assessed, and compared with sustainable energy development achievements in these countries. For testing the developed framework, comparative assessment methodology is applied, which consists of the following steps: the main sustainable energy development indicators were selected based on sustainable energy development targets in selected countries, the trends of sustainable energy development indicators of selected countries were compared and discussed by identifying the similarities and differences and the main reasons for this; CSR reports of energy utilities were analysed, assessed, and compared based on sustainable energy development targets by applying scores; the impact of CSR initiatives of energy utilities on sustainable energy development was appraised based on comparative assessment. The strength of the applied approach is simplicity and application of both qualitative analysis and quantitative data, and the limits are mainly linked to the subjectivity of the applied approach. The remainder of this study is organized as follows. Section 2 provides a literature review. Section 3 introduces the methods and data. Section 4 presents the results and Section 5 discusses the results and findings of analysis that was conducted. Section 6 concludes and provides policy implications for the other world countries for faster sustainable energy development and climate change.

\section{Literature Review}

Energy utilities are considered to be the most important public companies, since they provide energy to homes, businesses enterprise, etc. Traditionally, energy utilities relied on fossil fuels like oil and coal to generate and supply electricity to the grid [51]. This reliance on fossil fuels is currently a major issue for investors and society, as burning fossil fuels causes challenges for society due to climate change [52]. Due to the significant effects on the environment, energy utilities are considered as "high impact" entities. In addition, the energy utility industry is undergoing unprecedented transformations in the entire energy chain, including power generation, transmission, distribution, and trading. All utilities have to work to increase the value of the service that they provide to their customers. Incorporating renewable energy, energy efficiency measures, and other sustainable business practices allow utilities to serve their customers better, avoid revenues losses, and improve their financial situation [45]. Renewables and distributed energy sources are to be integrated into the performance of energy utilities, though they are experiencing huge uncertainties in the market and regulatory environments. Energy utilities are forced to advance their environmental performance and reduce supply costs by maintaining system reliability at the same time [52]. Thus, energy utilities are currently required to reconsider their business models and financial arrangements, launch new partnerships, and adapt their communication based on their goals, types of customers, etc. In addition, energy utilities are facing the challenges of a sharing economy in a similar way to new business platforms like Uber and Airbnb. Therefore, it is possible that the next breakout platform could be the energy sector because of micro-grid technology.

Corporate social responsibility (CSR) has gained reputation recently, and energy companies started to recognize their responsibility for society and the environment. Due to the current challenging changes in the energy industry and increased competition in the energy markets, energy utilities can use CSR as a differentiation strategy to handle competitive demands from prosumers and other market players [50-54]. Corporate social responsibility (CSR) allows utilities to deal with the challenges of sustainable development, including climate change, and implement sustainable business practices and CSR reporting [10]. The analysis of CSR practices of energy utilities in various 
world countries (Brazil [7,8], Poland [9], The US [10,11], China [12,13], India, and Japan [14], and groups of countries [15-18]), indicated the importance of CSR for dealing with the major risks and challenges that the energy sector is facing, i.e., corruption risks [19-22] and other important drivers like competition [36-38], reputation [40], customers loyalty [41-53], and policies [39,53-55], etc.

Some studies showed that the main reasons for the deliberate adoption of sustainable business practices, such as corporate social responsibility, environmental, social or energy management standards and systems, etc. by energy utilities, are based mainly on institutional factors and less on the utilities' determination to respond to customers' needs [56-59]. The study by Przepiorka and Horn [53] proved that consumer trust in utilities is directly linked to their investments in renewable energy sources. In addition, the study proved that prosocial investments increase customers' trust in the energy utilities.

Many other studies [28-35] addressed the importance of CSR reporting for ensuring the sustainability of companies that are operating in the public sector. The study by Cantelle et al. [28] highlighted that public sector enterprises implement voluntary disclosure measures mainly in order to ensure their accountability for taxpayers in the context of codes of ethics. As public organizations are contributing to the public services, they are required by state legislation to disclose environmental and social information, as they need to facilitate their political accountability and strengthen political relationships (Mio, 2010 [29]). Several studies indicated that due to the legal and institutional environment, energy utilities are forced to employ many practices to ensure proper accountability and reporting to their stakeholders [7-10]. In particular, it is important for energy utilities to implement business practices that are having a positive effect on sustainable development and inform society about their sustainability routine $[17,20,23]$.

Several scholars claim that public companies seek to reduce ambiguity and costs in the future during the disclosure of information in the CSR reports (Vasi, King, 2012 [60]; Short and Toffel, 2008 [61]). The findings by Kraft (2018) [11] showed that many companies are keen to disclose non-financial information due to competitive market structures. Other scholars presented their findings demonstrating that utilities are encouraged to prepare their disclosure strategies to gain necessary economic resources and ensure their legitimacy. Some studies indicated that stakeholder pressures have a significant impact on the disclosure strategy of enterprises (Kraft, 2018 [11]). Firms with high public observation like energy utilities are forced to disclose non-financial information in order to maintain their image and reputation and avoid public criticism in the future [28,29].

Policies and measures that are imposed by the governments, aiming to promote CSR, are important drivers of CSR in the energy sector. These policies consist of legal instruments such as laws, directives, and regulations; economic initiatives based on financial support like awards, tax allowances, etc.; and informational measures, like education, campaigns, and networking instruments for stakeholder engagement. In the majority of countries, CSR reporting measures usually target large enterprises and state-owned companies. The main instruments for implementing the requirements for sustainability reporting are laws and regulations, codes of ethics or conduct, information dissemination measures, and other policies and measures like governmental strategies, action plans, and national reporting schemes and initiatives. Most instruments deal with information disclosure on certain environmental and social issues or general information on sustainability topics [39].

As energy utilities started to experience the pressure towards a complete accountability of sustainability performance only recently, scholars started to investigate these issues, and there are just a few empirical studies focusing on sustainability reporting. Some methodologies have been developed to assess the sustainability performance of energy utilities by applying various indicators, including composite indices (Von Schwedler, 2011 [30]). Most studies in the field of CSR of energy utilities dealt with the analysis of the content and the quality of sustainability reporting. The study by Laringa-Gonzalez et al. (2008) [31] investigated the experience of Swedish utilities in the disclosure of sustainability linked information via sustainability reports. Few sustainable development indicators for identifying the most important economic, social, and environmental areas were developed [31]. Reed (1999) [55] argued that the linkages between the different CSR dimensions should be different in 
specific industries. The linkages between the main CSR dimensions, environmental, social, economic, and corporate governance in the power utility sector of the United States (U.S.), were investigated by Sidhoum and Serra (2018) [10]. Their results indicated quite a strong positive relationship between economic and environmental indicators. Meanwhile, a strong positive relationship between economic and social performance has been proven as well. However, there is no agreed framework to assess the CSR of energy utilities in terms of their contributions to the sustainable development of the energy sector. Therefore, in the following section of the paper, an attempt to develop such a framework is presented.

\section{Methods and Data}

The analysis performed in our paper is based on sustainable energy development indicators and comparative assessment approach. The applied assessment framework consists of the following steps: (i) the achievements of selected countries in sustainable energy progress are assessed by the selected sustainable energy indicators that represent the main sustainable energy development targets of the countries; (ii) the trends of sustainable energy indicators are compared and discussed by identifying the correspondences and dissimilarities, and the main causes of these; (iii) assessment of policies, including CSR, is performed based on an analysis of the corporate social responsibility reports of the energy utilities. The analysis and assessment of CSR reports of energy utilities are performed by applying scores according to three main areas of sustainable energy development. The policy implications are developed based on the assessment of CSR reports of utilities and accomplishments in the sustainable energy development of countries. The assessment framework is presented in a flowchart, depicted in Figure 1.

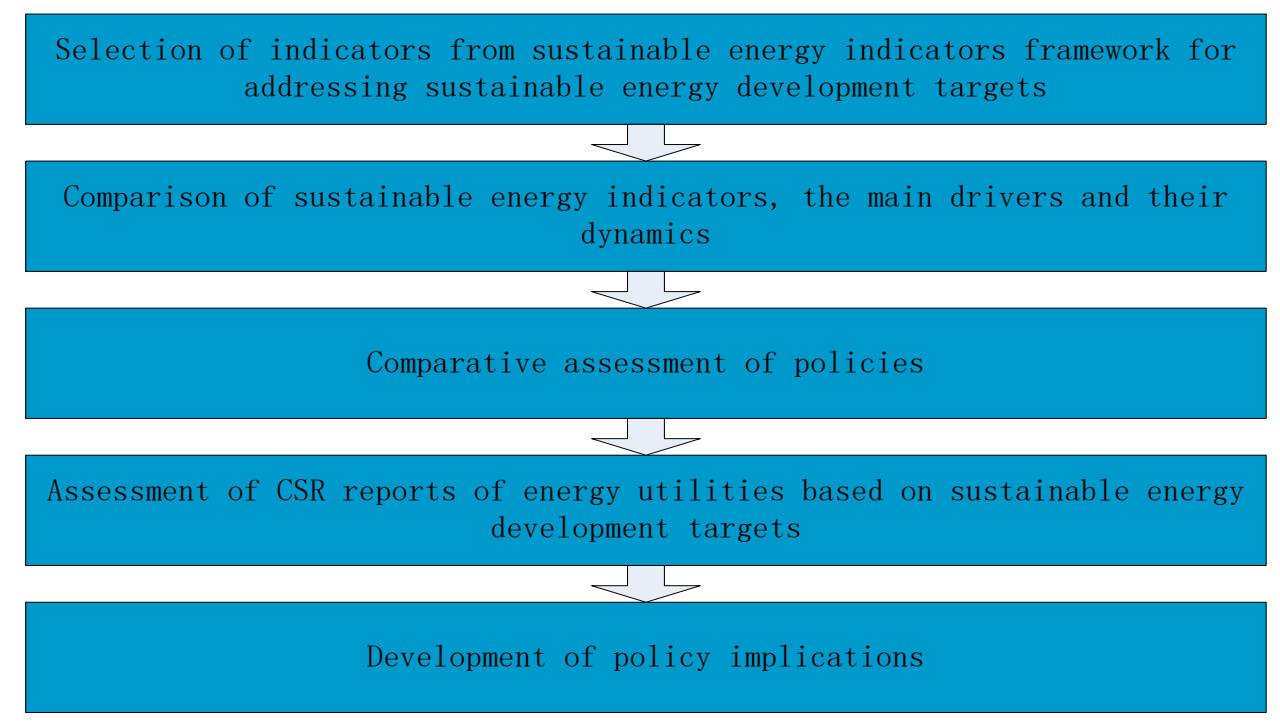

Figure 1. Methodology of the study. Source: created by the authors.

The main potency of the comparative assessment approach is its simplicity and usage of qualitative and quantitative analysis. This assessment framework allows tracking of the achievements of countries in sustainable energy development as well as scrutinizing the main factors that have an effect on these attainments. The main weakness of the applied framework is prejudice. The applied framework is replicable and can be employed for the comparative assessment of other policies and their effects in other countries.

The proposed comparative assessment framework will be applied for the case studies in three Baltic States (Latvia, Lithuania, and Estonia). The data used for comparative assessment case studies in the three Baltic States (Latvia, Lithuania, and Estonia) consists of indicators of sustainable development collected from the EUROSTAT database and data on renewable energy utilization, energy efficiency, 
and GHG emissions reduction collected in the CSR reports of energy utilities in Latvia, Lithuania, and Estonia. In the following sections of manuscript, the case studies are presented.

\section{Results}

4.1. Theoretical Framework for Linking CSR of Energy Utilities with Sustainable Energy Development Achievements Impact of CSR Initiatives of Energy Utilities on Sustainable Energy Development in the Baltic States

The results in achieving sustainable energy development targets of countries can be addressed by the framework of sustainable energy development indicators shown in Figure 2 and Table 1. The abbreviations in Table (ENV and EC) are spelled and they correspond to abbreviations presented in Figure 2.

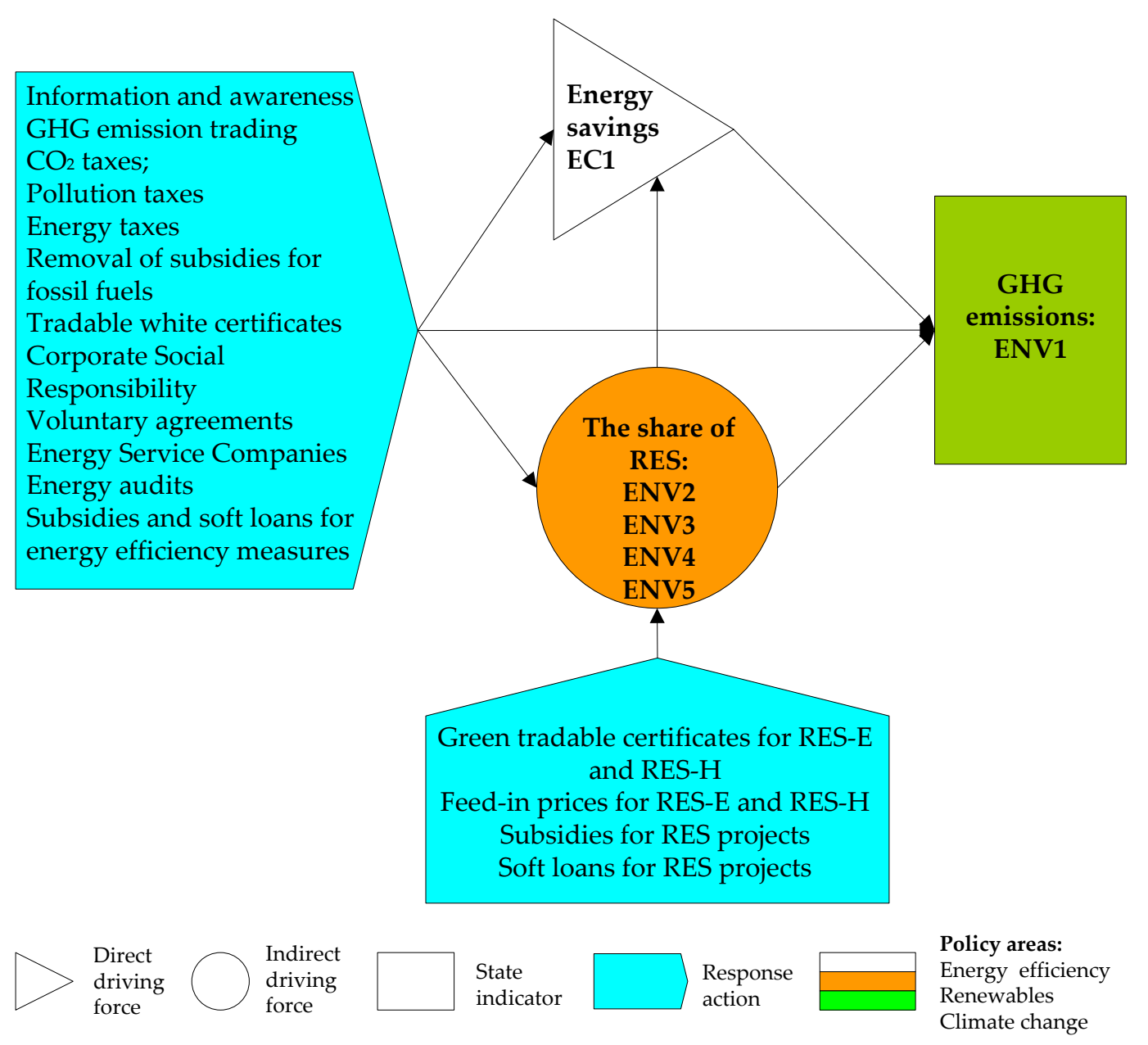

Figure 2. Linkages between sustainable energy indicators and policy actions including corporate social responsibility (CSR) of energy utilities. 
Table 1. Indicators of sustainable energy development. Source: created by the authors.

\begin{tabular}{cccc}
\hline Code & Indicator & Units of Measurement & $\begin{array}{c}\text { Target Value Under } \\
\text { Commitment }\end{array}$ \\
\hline EC1 & Economic Indicators (EC) & + \\
\hline ENV1 & $\begin{array}{c}\text { TPES (Total Primary Energy } \\
\text { Supply) reduction since 2005, ktoe }\end{array}$ & + \\
\hline ENV2 & $\begin{array}{c}\text { Greenhouse gas (GHG) emission } \\
\text { reduction comparing with the base year } \\
\text { Share of renewable energy sources }\end{array}$ & $\%$ & + \\
\hline ENV3 & $\begin{array}{c}\text { Share of renewable energy sources in } \\
\text { electricity generation (RES-E) }\end{array}$ & $\%$ & \\
\hline ENV4 & $\begin{array}{c}\text { Share of renewable energy sources } \\
\text { (RES) in transport (RES-T) }\end{array}$ & $\%$ \\
\hline ENV5 & $\begin{array}{c}\text { Share of renewable energy sources in } \\
\text { heating and cooling (RES-H) }\end{array}$ & $\%$ \\
\hline
\end{tabular}

As one can see from Table 1, there are three main interlinked sustainable energy development targets: increase in energy efficiency, use of renewable energy sources, and GHG emission reduction, which are represented mainly by environmental indicators from the IAEA framework [62]. The assessment framework presented in Figure 1 allows the linkages between CSR practices in the energy sector of the selected countries to be assessed by comparing sustainable energy development achievements in these countries based on the analysis of trends of sustainable energy development indicators (Table 1).

The main policies targeting sustainable energy targets are economic $\left(\mathrm{CO}_{2}\right.$ and pollution taxes), financial (subsidies and soft loans), or flexible market instruments (GHG emission trading, white and green tradable certificates). However, CSR of energy utilities, though a voluntary measure, is among the most important policies targeting sustainable energy development due to the importance of the role of energy utilities in the power sector.

Figure 2 presents the relationships between sustainable energy indicators that have been selected to address targets of sustainable energy policies in the country. The policies and measures are identified as response actions on sustainable energy indicators. The codes of the indicators in Figure 2 refer to the codes of sustainable energy indicators presented in Table 1. Some indicators of this assessment framework are the direct driving force, indirect driving, and state indicators (IAEA, 2005 [62,63]). The geometrical figures (triangle, ellipse, and quadrat) indicate the type of sustainable energy indicator in Figure 2.

All sustainable energy indicators that are presented in Figure 2 are linked to each other. The last indicator in this mutual impact chain is greenhouse gas emission, as policies (energy efficiency improvements, promotion of renewables, etc.) in the end have a positive effect on greenhouse gas emission reduction. All indicators are grouped based on the main sustainable energy policy areas: energy efficiency, renewables, and GHG emissions (Figure 2).

\subsection{Assessment of Sustainable Energy Development Trends and Approaching of Targets in the Baltic States}

The European Commission has adopted the main goals for 2020 in the energy sector based on the main dimensions of EU sustainable energy policy: energy supply security, competitive markets, and environmental sustainability. Energy efficiency improvement and the increase of the usage of renewable energy sources (RES) are the main drivers of GHG emission reduction.

Therefore, the main 2020 sustainable energy development targets for the EU are the following: (i) $20 \%$ reduction of GHG emissions compared to the base year (1990) level; (ii) $20 \%$ of renewables in final energy consumption, and (iii) 20\% increase in energy efficiency, compared with the level of 2005. 
The EU member states also agreed on a new framework for climate and energy for the year 2030 in 2014. These targets aim to assist the EU member states in achieving competitive, secure, and sustainable energy development and meet its long-term GHG reductions target for the year 2050. The main energy and climate targets for EU member states in 2030 are the following: (i) $40 \%$ reduction of GHG emissions compared to the base year level (1990), (ii) ensuring $32 \%$ of renewables in final energy consumption, (iii) increasing energy efficiency by $32.5 \%$ compared to the level of 2005 . The fourth target is a completion of the internal energy market by achieving an interconnection target of $15 \%$.

Therefore, the EU has made it mandatory that all 28 member states will have to source \% of their total energy outputs from renewables by 2020 and 32\% by 2030. Table 2 shows the share of renewables in the Baltic States in 2016 and the overall target of 2020. The RES indicators correspond to the sustainable energy indicators defined in Table 1 and Figure 2.

Table 2. National RES targets for the Baltic States in 2020 and results achieved in 2016. Source: created by the authors based on [64].

\begin{tabular}{ccccccc}
\hline $\begin{array}{c}\text { The Baltic } \\
\text { States }\end{array}$ & $\begin{array}{c}\text { Share of RES in } \\
\text { Heat (RES-H) } \\
\text { Consumption } \\
\text { in 2016, \% }\end{array}$ & $\begin{array}{c}\text { Share of RES in } \\
\text { Transport in } \\
\mathbf{2 0 1 6} \%\end{array}$ & $\begin{array}{c}\text { Share of RES in } \\
\text { Electricity } \\
\text { Sector (RES-E) } \\
\text { in 2016, \% }\end{array}$ & $\begin{array}{c}\text { Overall Share } \\
\text { of RES in the } \\
\text { Final Energy } \\
\text { Consumption } \\
\text { in 2016, \% }\end{array}$ & $\begin{array}{c}\text { Overall RES } \\
\text { Target in } \\
\text { 2020, \% }\end{array}$ & $\begin{array}{c}\text { Implementation } \\
\text { of 2020 RES } \\
\text { Target in 2016, } \\
\%\end{array}$ \\
\hline Latvia & 51.85 & 2.76 & 51.26 & 37.16 & 40 & 92.9 \\
\hline Estonia & 50.5 & 0.5 & 13.6 & 28.83 & 25 & 115.3 \\
\hline Lithuania & 46.07 & 3.63 & 16.82 & 25.46 & 23 & 110.9 \\
\hline
\end{tabular}

In terms of renewables, Estonia ranks as one of the EU leaders in terms of introducing electric and hybrid vehicles, and Lithuania aims to have $200 \mathrm{MW}$ of Photovoltaic (PV) capacity installed by 2020, which would make it the largest producer of solar energy in the region. Latvia, despite trailing its neighbors in terms of PV and wind power, is the Baltic States leader in hydropower. As it can be also seen from Table 2, Estonia stands out with very good results that are already overreaching the 2020 target by $115 \%$. In general, all the Baltic States, except Latvia, had already implemented their overall RES target for 2020 in 2016; however, Latvia is showing good progress and will be able to reach its RES target in 2020. In general, Latvia differentiates with the highest share of RES in final energy consumption due to high hydro capacities that are available in the country, having an impact on the high share of RES in power production and consumption.

The other important sustainable energy policy target is energy efficiency improvement. The EU member states reported on their progress towards the achievement of 2020 targets on energy efficiency improvements. In Table 3, the results of approaching the 2020 energy savings target for the Baltic States are presented. The energy savings indicator corresponds to the sustainable energy development indicators framework that is shown in Table 1 and Figure 2.

As one can notice from Table 3, Estonia yields the best results in the achievement of the 2020 target for energy efficiency improvement. However, it is clear that the Baltic States have problems with the implementation of energy savings targets that are set for 2020, especially Latvia, who is lagging in the implementation of the energy saving target. Other EU member states are experiencing problems with implementing energy efficiency targets for 2020 as well.

GHG emission reduction is linked to the energy efficiency improvement and penetration of renewables, as these are the main ways to reduce GHG emissions linked with fuel combustion. The growth of $15 \%$ compared to the level of 2005 is allowed for the Baltic States. The target for 2020 was recalculated according to the base year (1990) level. In Table 4, the GHG emissions in the Baltic States and targets that are set for 2020 are presented. GHG emission reduction targets and achievements by the Baltic States in 2016 are presented in Table 4. GHG emission reduction targets correspond to the sustainable energy development indicators framework presented in Table 1 and Figure 2. 
Table 3. National energy saving targets for the Baltic States in 2020 and results achieved until 2016. Source: created by authors based on [65].

\begin{tabular}{cccccccc}
\hline $\begin{array}{c}\text { The Baltic } \\
\text { States }\end{array}$ & \multicolumn{2}{l}{$\mathbf{2 0 1 6}$} & \multicolumn{4}{c}{ Progress Towards Target } \\
\hline $\begin{array}{c}\text { Energy } \\
\text { Savings, } \\
\text { ktoe }\end{array}$ & $\begin{array}{c}\text { Total } \\
\text { Annual } \\
\text { Savings, } \\
\text { ktoe }\end{array}$ & $\begin{array}{c}\text { Cumulative } \\
\text { Savings } \\
\text { over } \\
\mathbf{2 0 1 4 - 2 0 1 6}\end{array}$ & $\begin{array}{c}\text { Total } \\
\text { Cumulative } \\
\text { Savings } \\
\text { Required by } \\
\mathbf{2 0 2 0 , \text { ktoe }}\end{array}$ & $\begin{array}{c}\text { Progress } \\
\text { Towards } \\
\text { Cumulative } \\
\text { Savings in } \\
\mathbf{2 0 2 0} \%\end{array}$ & $\begin{array}{c}\text { Estimated } \\
\text { Annual Saving } \\
\text { Required } \\
\text { for 2014-2016, } \\
\text { ktoe }\end{array}$ & $\begin{array}{c}\text { 2014-2016 } \\
\text { Compared to } \\
\text { the Estimated } \\
\text { Annual } \\
\text { Savings, \% }\end{array}$ \\
\hline Latvia & 15 & 32 & 58 & 851 & 7 & 182 & 32 \\
\hline Estonia & 77 & 184 & 284 & 610 & 47 & 131 & 217 \\
\hline Lithuania & 23 & 86 & 188 & 1004 & 19 & 215 & 87 \\
\hline
\end{tabular}

Table 4. National GHG emission reduction targets for the Baltic States in 2020 and results achieved in 2005 and in 2016. Source: created by the authors based on [66].

\begin{tabular}{ccccc}
\hline The Baltic States & $\begin{array}{c}\text { GHG in 2005, } \\
\text { Compared with } \\
\text { the Base Year 1990, } \\
\text { \% }\end{array}$ & $\begin{array}{c}\text { 2020 GHG Target } \\
\text { Compared with } \\
\text { the Base Year 1990, } \\
\text { \% }\end{array}$ & $\begin{array}{c}\text { GHG in 2016 } \\
\text { Compared with } \\
\text { the Base Year 1990, } \\
\text { \% }\end{array}$ & $\begin{array}{c}\text { Progress Towards } \\
\text { 2020 GHG } \\
\text { Emissions Target } \\
\text { Achieved in 2016, } \\
\text { \% }\end{array}$ \\
\hline Estonia & 45.6 & 52.4 & 49.9 & 105.0 \\
\hline Latvia & 42.51 & 48.9 & 63.4 & 77.1 \\
\hline Lithuania & 47.75 & 54.3 & 58.3 & 93.1 \\
\hline
\end{tabular}

As one can notice from Table 4, Latvia shows the worst results in implementing GHG reduction targets, and Estonia shows the best results.

The comparative assessment revealed that the good results in implementing RES and energy saving targets achieved by Estonia correspond to the good results in implementing GHG reduction targets by the country. In the next section, the CSR of energy utilities will be assessed taking into account sustainable energy development targets: an increase in energy efficiency and the use of renewables and GHG emission reduction.

\subsection{Assessment of CSR Reports of Energy Utilities Based on Sustainable Energy Targets}

The performed literature analysis suggests that corporate social responsibility of energy utilities is among the most important policies and measures to ensure sustainable energy development in the country. For comparative assessment and ranking of CSR reports of selected countries and the linkages between CSR principles, sustainable development goals and sustainable energy development targets set by the countries are addressed.

The United Nations initiated the Global Compact, which is a key tool for corporate social responsibility aiming to inspire companies to run their business in a socially responsible way, not to harm the environment, and to benefit communities, by addressing specific social and environmental problems and contributing to sustainable economic development. CSR in the energy sector addresses social, economic, and environmental issues and is coherent with the concept of sustainable business. In Table 5 the relations between CSR principles, UN sustainable development goals (SDGs) and sustainable energy development targets of the Baltic States are provided. 
Table 5. Sustainable development goals, CSR principles, and sustainable energy development targets in Baltic States. Source: created by authors based on $[39,62]$.

\begin{tabular}{|c|c|c|}
\hline $\begin{array}{l}\text { UN Sustainable Development } \\
\text { Goals }\end{array}$ & CSR Principles According to Global Compact & $\begin{array}{l}\text { Sustainable Energy Development } \\
\text { Targets of Baltic States }\end{array}$ \\
\hline $\begin{array}{c}\text { Goal } 7 \text { Affordable and Clean } \\
\text { Energy }\end{array}$ & $\begin{array}{c}\text { Principle 7: Businesses should address a } \\
\text { precautionary principle to environment; } \\
\text { Principle 8: Business should implement } \\
\text { initiatives to encourage greater environmental } \\
\text { responsibility; } \\
\text { Principle 9: Business should promote the } \\
\text { diffusion of environmentally friendly } \\
\text { technologies }\end{array}$ & $\begin{array}{l}\text { The main sustainable energy } \\
\text { development targets: energy efficiency } \\
\text { improvement and increase of the usage } \\
\text { of RES correspond to this goal }\end{array}$ \\
\hline $\begin{array}{c}\text { Goal } 8 \text { Decent Work and Economic } \\
\text { Growth }\end{array}$ & $\begin{array}{c}\text { Principle 4: Business should eliminate forced } \\
\text { and compulsory labor in all its forms; } \\
\text { Principle 5: Business should seek the complete } \\
\text { abolition of child labor; } \\
\text { Principle 6: Business should strive abolition all } \\
\text { forms of employment and occupation } \\
\text { discrimination }\end{array}$ & $\begin{array}{c}\text { Energy efficiency improvement and } \\
\text { increase of the usage of RES is linked } \\
\text { with development of new technologies } \\
\text { and have direct impact on economic } \\
\text { growth and employment }\end{array}$ \\
\hline $\begin{array}{c}\text { Goal } 9 \text { Industry, Innovation, and } \\
\text { Infrastructure }\end{array}$ & $\begin{array}{l}\text { Principle 9: Business should support the } \\
\text { penetration of environmentally friendly } \\
\text { technologies }\end{array}$ & $\begin{array}{c}\text { Energy efficiency improvement and } \\
\text { increase of the usage of RES are linked } \\
\text { with innovations and development of } \\
\text { new technologies, industries, and } \\
\text { infrastructure }\end{array}$ \\
\hline $\begin{array}{l}\text { Goal } 11 \text { Sustainable Cities and } \\
\text { Communities }\end{array}$ & $\begin{array}{l}\text { Principle 9: Business should support the } \\
\text { penetration of environmentally friendly } \\
\text { technologies }\end{array}$ & $\begin{array}{l}\text { Energy efficiency improvement and } \\
\text { increase of the usage of RES are the } \\
\text { main issues addressed by Sustainable } \\
\text { Cities and Communities }\end{array}$ \\
\hline $\begin{array}{l}\text { Goal } 12 \text { Responsible Consumption } \\
\text { and Production }\end{array}$ & $\begin{array}{l}\text { Principle 9: Business should support the } \\
\text { penetration of environmentally friendly } \\
\text { technologies }\end{array}$ & $\begin{array}{l}\text { Energy efficiency improvement and } \\
\text { increase of the usage of RES are the } \\
\text { main issues addressed by responsible } \\
\text { consumption and production }\end{array}$ \\
\hline Goal 13 Climate Action & $\begin{array}{c}\text { Principle 7: Business should address a } \\
\text { precautionary principle to environment; } \\
\text { Principle 8: Business should implement } \\
\text { initiatives to encourage greater environmental } \\
\text { responsibility; } \\
\text { Principle 9: Business should support the } \\
\text { penetration of environmentally friendly } \\
\text { technologies }\end{array}$ & $\begin{array}{c}\text { Climate change mitigation in the energy } \\
\text { sector is directly linked to energy } \\
\text { efficiency improvement and increase of } \\
\text { the usage of RES }\end{array}$ \\
\hline $\begin{array}{l}\text { Goal } 16 \text { Peace, Justice, and Strong } \\
\text { Institutions }\end{array}$ & $\begin{array}{l}\text { Principle 3: Business should support the } \\
\text { freedom of association and the right to } \\
\text { collective bargaining; } \\
\text { Principle 10: Business should fight against all } \\
\text { forms of corruption }\end{array}$ & $\begin{array}{c}\text { For implementation of energy efficiency } \\
\text { improvement and increase of the usage } \\
\text { of RES, strong institutions are also } \\
\text { necessary }\end{array}$ \\
\hline
\end{tabular}

As it becomes apparent from Table 5, the main UN sustainable development goals (SDGs) linked to sustainable energy development targets (energy efficiency improvements, usage of renewable energy sources, and GHG emission reduction) and CSR principles set by Global Compact are based on environmental sustainability. These SDGs address affordable and clean energy, industry, innovation and infrastructure, responsible consumption and production, smart cities and communities, and climate actions. Labor and human rights principles implied by CSR are linked with the decent work and economic growth goal and not directly related to sustainable energy development targets.

The assistance of energy utilities with various issues of sustainability has been critically argued by various stakeholders during recent decades. The starting point for this was the development of new public management theory promoting energy market liberalization seeking to deal with economic inefficiencies of state-owned energy utilities [4]. Market liberalization enforced the emergence of new requirements for accountability and reporting and monitoring of public interest-driven energy service obligations [67,68]. The power sector decentralization, unbundling, and liberalization imposed new requirements for the regulation in this sector, like access, availability, and affordability for the private sector, quality, tariffs, etc., in order to ensure public value worries [69]. In addition, electric utilities are under huge pressure due to their perceived negative impacts on climate change [70] and are forced by governments to provide input for the de-carbonization objectives of the countries imposed by the Paris 
Agreement of 2015. An additional inspiration for concentrating on sustainability reporting of energy utilities is the Global Reporting Initiative (GRI) guidelines that were issued for the power sector for the disclosure of information, taking into account the specific role of power utilities that are contributing to sustainable development [71].

The key sustainability reporting frameworks for energy utilities are the Global Reporting Initiative (GRI), Global Compact guidelines, and Sustainability Accounting Standards Board (SASB). There is a great likeness between the GRI sector supplements and SASB industry standards for the energy utilities with small differences like the establishment of a more thorough industry-specific review in the GRI-G4 energy sector supplement compared to the SASB [16].

All three utilities in the Baltic States are involved in corporate social responsibility practices and submit annual reports; however, the reporting periods are very different; therefore, CSR assessment should be conducted for the last available year, i.e., 2018. As energy utilities in the Baltic States do not apply the same structure of reporting, there is no other way to assess the CSR level of these utilities. Latvian energy utility Latvenergo is a GRI member and has appled GRI guidelines for reporting since 2009. The company submitted 10 CSR reports. Lithuanian energy utility Lietuvos Energija has been a member of Global Compact since 2016 and has submitted 3 CSR reports by applying Global Compact guidelines for corporate responsibility reporting. Estonian energy utility Eesti Energia has introduced the principles of the Combined Code on Corporate Governance of the United Kingdom's Financial Reporting Council since 2013 and applies the Baltic Guidance on the Governance of Government-owned Enterprises of the Baltic Institute of Corporate Governance for CSR reports. Having such diversity of CSR reporting, it is necessary to develop criteria for assessing CSR levels of energy utilities in the Baltic States.

The main criteria for the assessment of the CSR of energy utilities are developed based on several studies (Sartori et al., 2017 [7]; Camargos et al., 2014 [8]; Sidhoum and Serra, 2017 [10]; Kraft, 2017 [11]; Chang, 2013 [12]; Bahari et al., 2016 [14]; Traxler and Greiling, 2017 [16]; Talbot and Boiral, 2018 [17]; Przepiorka and Horne, 2018 [53]) and include the extent of CSR reporting, the quality of CSR reporting, the achieved results, and the envisaged actions in three main sustainable energy areas: energy savings, use of renewables, and GHG mitigation as these are the main sustainable energy development targets. Scores from 1 to 5 are applied for the assessment of the CSR of energy utilities in three environmental areas linked to this study: energy savings, use of renewables, and GHG emissions.

The extent of reporting will be assessed on a five-point scale in three main sustainable energy areas: 5 represents all important information is disclosed; 4 represents important areas and information are disclosed; 3 represents few important areas are disclosed; 2 represents limited information is disclosed; 1 represents extremely low disclosure of information.

The quality of reporting will be assessed on a five-point scale in three main sustainable energy areas: 5 indicates superior quality of reporting, including comprehensive quantitative indicators for monitoring; 4 indicates very good quality of reporting, including the most important quantitative indicators; 3 indicates moderate quality of reporting, including very few quantitative indicators; 2 indicates low quality of reporting based on qualitative evaluations; 1 indicates extremely low quality of reporting based on general descriptions.

The following categories are established on a five-point scale for the achieved results in three main sustainable energy areas: 5 represents superior results are achieved; 4 represents significant results are achieved; 3 represents moderate results are achieved; 2 represents limited results are achieved; 1 represents extremely limited results are achieved.

The following categories are established on a five-point scale for envisaged action of utilities in environmental areas under consideration: 5 indicates advanced policy actions are envisaged; 4 indicates significant actions and a long-term vision are envisaged; 3 indicates some actions are envisaged; 2 indicates limited actions are envisaged; 1 indicates extremely limited actions are envisaged.

In Table 6, the criteria for the assessment of CSR of utilities are provided. 
Table 6. The criteria for the assessment of CSR of utilities. Source: created by the authors.

\begin{tabular}{clll}
\hline $\begin{array}{c}\text { Criteria for the CSR } \\
\text { Assessment }\end{array}$ & Energy Savings & Use of Renewables & $\begin{array}{c}\text { GHG Emission } \\
\text { Reduction }\end{array}$ \\
\cline { 2 - 4 } & Scores: from 1 to 5 & Scores: from 1 to 5 & Scores: from 1 to 5 \\
\hline The extent of reporting & Scores: from 1 to 5 & Scores: from 1 to 5 & Scores: from 1 to 5 \\
\hline The quality of reporting & Scores: from 1 to 5 & Scores: from 1 to 5 & Scores: from 1 to 5 \\
\hline Achieved results & Scores: from 1 to 5 & Scores: from 1 to 5 & Scores: from 1 to 5 \\
\hline Envisaged actions & & &
\end{tabular}

As one can see from Table 6, the CSR reports of energy utilities will be assessed using 12 criteria. The highest ranking for CSR of energy utility will allow a score 60 and the lowest one 12 .

Latvenergo Group has more than 3,000 employees and this company is one of the largest power suppliers in the Baltics. It operates in the power and heat generation sectors and trade, power distribution services, and the lease of transmission networks. Latvenergo has been a member of the GRI reporting initiative since 2009 and has prepared 10 sustainability and annual reports from 2009 to 2018. The annual sustainability reports prepared by the company are in line with the quality assurance principles developed in the GRI (Global Reporting Initiative) guidelines: non-financial reporting on the basis of internationally recognized reporting guidelines; stakeholder commitment; charity and donations; scholarships and support for research and development.

The following are the environmental policy priorities of the company: GHG emission reduction; efficient use of natural resources; implementation of the main principles of cleaner production and green procurement that may affect the environment; conservation of biodiversity; promotion of public environmental awareness. The sustainability and annual report of Latvenergo in 2018 was prepared according to the GRI Guidelines G4 for the energy utilities sector [72].

According to the extent of reporting in the main targeted areas, Latvenegro can be evaluated with overall high scores. According to the extent of reporting on energy savings, the company presents several indicators that are linked to energy savings: average generation efficiency of the thermal plants by the energy source by regulatory regime, distribution losses as percentage of total energy, and average availability factor of the energy source. The same score is allocated to the extent of reporting 4 and quality of information 4. The quantitative indicators are given in time series from 2011 in order to assess the achieved results. All these indicators show positive trends during the 2011-2017 period, except the plant availability factor for Daugava HPP, which decreased during the investigated period. Therefore, for the achieved results in the energy saving area, a high score 4 is allocated. For the envisaged actions, a score of 3 is allocated, as from the CSR report, it is difficult to find a comprehensive list of actions that are targeting this area.

According to the extent of reporting on the usage of renewables, the highest score 5 is allocated. The company presents a comprehensive disclosure of information on RES under specific GRI index: materials used by weight or volume and energy consumption. The following RES indicators have been provided since 2011 in dynamics: consumption of RES in primary energy, use of RES for electricity generation, and use of wood for thermal energy generation. The quality of information on RES can be assessed as well with the highest score 5, as information is given in physical units and percentages. The achieved results in RES area can be assessed by a lower score 4, as the share of RES (mainly hydro) has been decreasing in the electricity mix, though the share of wood in thermal energy generation has increased significantly during the investigated period. According to the foreseen actions, quite a low score 3 is allocated, as there are no concrete numbers presented in the CSR report on the future extension of the use of renewables for energy generation in Latvenergo companies.

According to the extent of reporting on GHG emission reduction, Latvenergo is scored with a high score 4, as just a few indicators for the GHG emissions are disclosed, i.e., direct GHG emission and GHG emission intensity per MWh of the generated electricity. Other indicators like life cycle 
GHG emissions or GHG emission reduction information is not fully disclosed. The highest score 5 is allocated for the quality of reporting on GHG emission reduction, as GHG emission indicators are presented in dynamics: direct GHG emissions and GHG emission intensity since 2011. According to the achieved results in GHG emission reduction, quite a low score can be allocated 2, as GHG emission intensity is rising though direct GHG emission is fluctuating. However, since 2015, the trend in the increase of GHG emissions can be noticed. This is due to the decrease of electricity that was generated by the Daugava HPP (hydropower plant) due to low water flow. According to the envisaged actions on the GHG emission reduction, the average score 3 is allocated, as the situation with Daugava HPP is unclear because of climate change that is having an impact on the water flow reduction. Other measures that are foreseen for the GHG emission reduction are linked to energy efficiency improvements and the intensification of biomass usage for the thermal heating.

Lietuvos Energija Group is a state-owned company that has more than 4,000 employees. It operates the main Lithuanian electricity generation capacities, nation-wide electricity, and natural gas distribution network and supplies electricity and natural gas to its customers. Lietuvos Energija has been a member of Global Compact since 2016; the company employs new technologies, and their processes are having a positive impact on mitigation of environmental impact. Lietuvos Energija group works on waste recycling and efficient management of all resources. The company has submitted 3 CSR reports by applying Global Compact guidelines for corporate responsibility reporting since 2016. The corporate social responsibility report that was produced in 2018 covers 5 key areas: employees' protection and human rights, environmental protection, anti-corruption activities, responsibility in the market, and relations with communities [73].

According to the extent of reporting on energy savings criteria, the utility can be scored with quite a low score 3, as the company presents very limited information on various areas of energy savings like withdrawal of inefficient equipment in electricity generation, initiation of green protocol and the days of safe and rational use for the residents, the implementation of the energy service company (ESCO) model for energy saving, and development of co-generation power plants. The quality of information on energy and resource savings is low 2. There are no quantitative indicators for energy savings presented in the reports in dynamics. Only a general description of resource savings is presented as reduction of paper consumption and switching to electronic bills and video conferences in order to cut the number of trips. The achieved results in the energy saving area also scored quite a low score 3, as too little information is provided for the assessment of real progress. For the envisaged actions, the highest share 5 is allocated, as there is a list of comprehensive actions, targeting the area of further development of the ESCO model services, by completing a pilot project in smart accounting in order to facilitate customers in efficient time, and electric energy management; implementation of projects on great efficiency, modern co-generation power plants powered by waste, and biofuel in Vilnius and Kaunas, implementation of long-term initiatives such as "As much as needed" for energy saving in industrial enterprises, educational projects "Elektromagija" for safe handling of electricity and "A Sustainable School" for encouraging the educational institutions to save energy; activities within Green protocol for industries, days of safe and rational electricity use for residents, renewal of the ESO distribution power grid; implementation of modern, efficient, and safe technologies, etc.

According to the extent of reporting on the usage of renewables, the average score 3 is allocated. The company presents information on RES by identifying energy generation from renewables. The quality of information on RES can be scored with an average score 3. There are some quantitative indicators for energy generation from renewables that are presented for the specific year of reporting. The achieved results in RES area can be assessed by a higher score 4, due to important information about the usage by the company of energy only from renewable sources, investments in two wind power plants, installation of new biofuel boiler capacities, etc. According to the foreseen actions, the highest score 5 is allocated, as there are many actions foreseen in this area and presented in the CSR report: promotion of electric cars, an electricity exchange that was initiated with customers who installed small solar power plants, installation of new biofuel boilers at the largest thermal power 
plant in Elektrenai, the renewable energy certificates of origin that were installed and distributed, the 500 MW capacity wind plants that are planned to be acquired.

According to the extent of reporting on GHG emission reduction, Lietuvos Energija is scored with a high score 4, as the main indicators for GHG emissions are disclosed: direct GHG emission and GHG emission intensity per MWh of the generated electricity. Other indicators like life cycle GHG emissions or GHG emission reduction information is not fully disclosed. The highest score 5 is allocated for the quality of reporting on GHG emission reduction, as GHG emission indicators are presented in dynamics: direct GHG emissions and GHG emission intensity since 2012. According to the achieved results in GHG emission reduction, quite a high score can be allocated 4, as GHG emission drastically declined during the investigated period. The GHG intensity of electricity production was fluctuating; however, the trend of decrease can be noticed from the presented information: in March 2017, Lietuvos Energija completed a project on dismantling the decommissioned units 1 and 2 of the reserve power plant at Elektrenai. According to the envisaged actions on GHG emission reduction, the average score 3 is allocated, as there are no concrete actions on GHG reduction that are foreseen in the CSR reports, just an action foreseen for energy savings and increased use of RES can be considered as GHG emission reduction actions.

Eesti Energia is a state-owned international energy company with more than 6,000 employees that are operating in the local electricity and gas markets and international liquid fuels market. The company supplies power, heat, and fuel, and ensures production, sales, and customer service, including ESO activities. The company has unique experience and technology in oil shale processing and power generation from oil shale, which is highly appreciated around the world. The company applies good corporate governance principles in line with Estonian legal acts. It is following the principles of the Combined Code on Corporate Governance of the United Kingdom's Financial Reporting Council and the principles of the Corporate Governance Code that is approved by the Estonian Financial Supervision Authority. Moreover, the company observes the principles of the Baltic Guidance on the Governance of Government-owned Enterprises prepared by the Baltic Institute of Corporate Governance. The company sets its social responsibility goals in four dimensions of its activities: employee, customer, environment, and community. It has implemented the international standards ISO 14001 and Environmental Management and Audit Scheme (EMAS).

Since 2015, Eesti Energia (EE) has been issuing information about environmental protection and other sustainable practices in their corporate social responsibility report and annual report. Based on an analysis of the CSR report for 2018, the following scoring is provided [74].

According to the extent of reporting on energy savings criteria, the utility can be scored at quite a high score 4. EE presents detailed information on various areas of energy savings. The quality of information on energy and resource savings is quite low 3 . There are no quantitative indicators for energy savings presented in reports on dynamics; only a general description of resource savings is presented. The achieved results in the energy saving area also scored the same score 3 , as there is no information to assess the real progress that was achieved, just a description of new technologies and implementation of material and resources saving practices. For envisaged actions, the highest score 5 is allocated, as there is a list of comprehensive actions targeting this area.

According to the extent of reporting on the usage of renewables, the highest score 5 is allocated. The company presents very comprehensive information on RES by identifying energy generation from renewables, installed renewable capacities by RES source, etc. The quality of information on RES can be scored with a high score 4 as well. The main quantitative indicators for energy generation from renewables are presented for a specific year of reporting, and some dynamics are given. The achieved results in the RES area can be assessed by the highest score 5, as reports present very clear and detailed information on achieved results in the increase of usage of RES. The company has the most diverse renewable energy sources of all the regions of the Baltic Sea. The energy is produced from wind, solar, biomass, municipal waste, and hydro. The renewable energy production capacity has tripled during the three consecutive years. According to the foreseen actions, the highest score 5 is allocated as well. 
Large investments in renewable energy sources are planned. It is foreseen that the share of electricity produced from renewable and alternative sources will account for $40 \%$ of output in 2022. Detailed actions are foreseen to achieve this target: capturing the renewable energy investment opportunities locally and raising additional capital by public offering. EE is planning to produce renewable energy in Estonia and other countries in the region.

According to the extent of reporting on GHG emission reduction, Eesti Energia is scored with the highest score 5, as comprehensive GHG emission indicators are disclosed: direct GHG emission and GHG emission intensity per MWh of the generated electricity, achieved GHG emission reductions, etc. The highest score 5 is allocated for the quality of reporting on the GHG emission reduction, as GHG emission indicators are presented in dynamics. According to the achieved results in GHG emission reduction, the highest score 5 is allocated, as GHG emission drastically declined during the investigated period. According to the envisaged actions on GHG emission reduction, the highest score 5 is allocated. EE presents concrete actions on GHG reduction that are foreseen and mainly linked with the implementation of new technologies in the oil shale industry. The planned increase in utilization of RES will have a significant impact on climate change mitigation as well.

The ranking of three energy utilities from the Baltic States based on their CSR reports, as analyzed in detail above, is provided in Table 7.

Table 7. The ranking of three energy utilities from the Baltic States. Source: created by the authors.

\begin{tabular}{|c|c|c|c|}
\hline \multirow{2}{*}{ Criteria for the CSR Assessment } & \multicolumn{3}{|c|}{ Scores } \\
\hline & Latvenergo & Lietuvos Energija & Eesti Energia \\
\hline The extent of reporting in the energy saving area & 4 & 3 & 4 \\
\hline The extent of reporting in the usage of renewables & 5 & 3 & 5 \\
\hline The extent of reporting in the GHG emission reduction & 4 & 4 & 5 \\
\hline The quality of reporting in the energy savings area & 4 & 2 & 3 \\
\hline The quality of reporting in the usage of renewables & 5 & 3 & 4 \\
\hline The quality of reporting in the GHG emission reduction & 5 & 5 & 5 \\
\hline Achieved results in the energy savings & 4 & 3 & 3 \\
\hline Achieved results in the usage of renewables & 4 & 4 & 5 \\
\hline Achieved results in the GHG emission reduction & 2 & 4 & 5 \\
\hline Envisaged actions in the energy savings & 3 & 5 & 5 \\
\hline Envisaged actions in the increased usage of renewables & 3 & 5 & 5 \\
\hline Envisaged actions in the GHG emission reduction & 3 & 3 & 5 \\
\hline Total score & 46 & 44 & 54 \\
\hline
\end{tabular}

As one can notice from information given in Table 7, the energy utility in Estonia received the total highest score in assessing CSR reports according all criteria. The Eesti Energia stands out with very high scores in reporting on GHG emission reduction and use of renewable energy sources.

\section{Discussion}

Energy utilities and their corporate social responsibility obligations play an important role in implementing sustainable energy development targets in the country. There are three main interlinked sustainable energy development targets in the EU set for 2020, extended for 2030 and 2050: increase in energy efficiency, use of renewable energy sources, and GHG emission reduction. The results in achieving these targets set for 2020 by the three Baltic States were compared to an assessment of the CSR of energy utilities in these countries based on the extent and quality of CSR reporting, the achieved results, and the envisaged actions in three main sustainable energy development areas: energy savings, use of renewables, and GHG emission reduction. 
The comparative analysis that was conducted in this paper confirms that these results are also available in other studies that were analyzed in this paper [3,5-7], indicating the importance of CSR for the energy sector and taking into account the high impact of this sector and various risks [19,21,22]. The studies found that the contribution of energy utilities to sustainability issues can be pursued either by integrating principles of sustainability into an organization's operations (such as limited environmental impacts and regard to society and stakeholders) or by supervision of all activities and resources management, taking into account the sustainability principles $[38,53,58]$.

The exceptional role of CSR reporting in the energy sector $[10,16]$ for information disclosure for the investors in the renewable energy sources that was highlighted in the other studies has been confirmed by the empirical study that was conducted in the Baltic States on the assessment of the CSR of energy utilities.

Based on the empirical results of case studies for comparative assessment of the CSR of energy utilities for three Baltic States, it was determined that the best results in implementing sustainable energy policy targets in all areas (increase in energy efficiency, use of renewables, and GHG emission reduction) were achieved by Estonia. The assessment of CSR of Estonian energy utility Eesti Energia, based on a CSR report for the year 2018, provided the highest score in terms of input to the implementation of sustainable energy development targets (increase in energy efficiency, use of renewables, and GHG emission reduction) of the country. Especially high ranking of achieved results in implementing sustainable energy development targets and envisaged actions for the implementation of these goals is achieved for Eesti Energia, compared with the other energy utilities in the region. Though Eesti Energia is not a member of GRI or Global Compact, the company is developing comprehensive corporate social responsibility reports and follows the strict requirements of the Code of Ethics.

Though Latvian energy utility is a member of the GRI and provides comprehensive CSR reports based on GRI guidelines, the CSR assessment of Latvenergo based on sustainable energy priorities (increase in energy efficiency, use of renewables, and GHG emission reduction) provided lower ranking, especially according to the achieved results and envisaged actions. This corresponds to the assessment of results of the country in approaching sustainable energy development targets (increase in energy efficiency, use of renewables, and GHG emission reduction), which are the lowest among the Baltic Countries.

Lithuanian energy utility Lietuvos Energija is a member of the Global Compact. The company prepares corporate responsibility reports; however, information disclosure and quality of information is quite low in these reports. Furthermore, the scoring on achieved results in implementing the main sustainable energy development is quite high for this company. Lietuvos Energija has achieved very similar to Latvenergo in overall ranking in CSR assessment. However, the higher scores of the company for the achieved results and envisaged actions in approaching sustainable energy targets corresponds to the higher ranking of the country in terms of implementation of sustainable energy development targets.

Our study has some limitations as the comparative assessment approach applied in the study is subjected to several boundaries. The CSR of energy utilities is a very important driver of sustainable energy development targets in the country. However, the actions of other energy sector players are important as well. There are many policies and measures developed by countries to pursue sustainable energy development as provided in Figure 2; however, energy utilities play a crucial role in delivering sustainable energy development targets. CSR obligations and practices of energy utilities can be treated as crucial issues in achieving sustainable energy development targets of the country.

The limits of the applied approach are related to the subjectivity in addressing the influence of the CSR of energy utilities on the achievement of the sustainable energy development targets of the countries. Future investigation is foreseen seeking to add some advanced policy analysis tools like decomposition analysis of GHG emission in the energy sector, multi-criteria decision aiding tools for the assessment of sustainable energy development trends, and to perform assessment of CSR reports and sustainable energy development trends in dynamics. 


\section{Conclusions}

Sustainable energy development is one of the most important issues linked to global risks and uncertainties such as climate change, fuel poverty, hunger, and instability. The main UN sustainable development goals (SDGs) directly linked to sustainable energy development targets (energy efficiency improvements, usage of renewable energy sources, and GHG emission reduction) and CSR principles set by Global Compact are based on environmental sustainability. These SDGs address affordable and clean energy, industry, innovation and infrastructure, responsible consumption and production, smart cities and communities, and climate actions.

The corporate social responsibility of energy utilities is the main business initiative helping to deal with major risks and provides for sustainable energy development due to the impact that the industries of energy utilities have on climate, local communities, and the economy as a whole.

Measuring and managing the corporate social responsibility issues that are linked to sustainable energy development can help to provide both energy utilities and investors in the sector with a better understanding of their businesses and a clear pathway to keep consumer costs low while shifting to new energy saving technologies and a renewable energy portfolio.

CSR reports of energy utilities provide measures to assess the true impact of energy utilities on the sustainable energy development of the country and the costs of their operations.

The conducted comparative assessment study in the Baltic States revealed the important linkages between three main interlinked sustainable energy development areas: i) energy efficiency improvement, ii) use of renewables, and iii) climate change mitigation. The analysis and assessment of achieved results in approaching sustainable energy targets (energy efficiency improvements, use of renewables, and climate change mitigation) of the three Baltic States by applying a framework of sustainable energy indicators ranked Estonia as the country which achieved the best results in approaching all sustainable energy development targets (Estonia was followed by Lithuania). In terms of renewables, Estonia stands out with very good results that are already overreaching the 2020 target by $115 \%$. Estonia demonstrated the best results in the achievement of the 2020 target for energy efficiency improvement and GHG emission reduction. Latvia differentiates with the highest share of RES in final energy consumption due to high hydro capacities that are available in the country, having an impact on the high share of RES in the power production and consumption; however, the progress achieved by the country in RES, energy efficiency, and GHG reduction is the lowest among the Baltic States.

The assessment and ranking of CSR of energy utilities in the Baltic States also indicated the highest ranking according to sustainable energy development criteria (disclosure of information, quality of information, achieved results, and envisaged actions) of Estonian energy utility. The CSR of Latvian and Lithuanian energy utilities are ranked with similar significantly lower scores. This allows us to confirm the importance of energy utilities and their CSR obligations and practices on delivering sustainable energy development goals.

Considering the importance of the CSR of energy utilities for achieving sustainable energy sector development, various public policies to promote CSR should be implemented, ranging from legal instruments such as laws, directives, regulations, and various financial instruments (awards, tax allowances) to informational measures and stakeholder networking. Sustainability reporting can be imposed by codes of ethics, voluntary measures, informative measures, obligatory mandates or standards, and other public policies: government strategies and national schemes for disclosure of non-financial information.

The main policy implication of this study is the promotion of the CSR of energy utilities by encouraging them to implement comprehensive CSR reporting practices and provide high quality quantitative information disclosure on the most important sustainable energy development indicators related to energy efficiency, renewables, and GHG emission reduction. The information disclosure on achieved results in implementing sustainable energy development targets and envisaged actions in this area can also provide investors with necessary information and ensure lower consumer costs 
while dealing with GHG emission reduction and implementing renewable energy and other advanced technologies, as well as smart management practices.

The proposed comparative assessment framework can be applied for the assessment of CSR of energy utilities in other countries and linking these assessments with sustainable development targets that are approached by the countries. The replicability of this study is very useful for developing global cooperation projects like the Belt and Road Initiative (BRI) that was initiated by the Chinese government, covering climate smart infrastructure development and investments in related areas: renewables, energy efficient technologies, smart grids, etc.

Our study has several limitations. The limitations of the applied methodology are mainly related to the prejudice in assessing the influence of CSR on the achievement of sustainable energy development targets. Future investigations would be useful by adding some advanced policy analysis tools to the conducted analysis. Such tools include the decomposition of GHG emissions in the energy sector by the main drivers: energy efficiency improvements, increase use of renewables, and economic growth. The dynamic perspective in analysis and assessment of CSR reports should be applied. Application of multi-criteria decision analysis (MCDA) tools would allow sustainable energy development trends in countries to be assessed and compared by integrating all indicators in one index to track its development. These more robust methods and tools would allow the extension of the scope of the conducted study and generate relevant supplementary findings.

Author Contributions: conceptualization, J.L., L.R., W.S., and J.S.; methodology, W.S.; validation, S.Y.; formal analysis, W.S. and J.Q.; investigation, J.Q. and L.R.; data curation, S.Y.; supervision, L.R.; writing一original draft preparation, J.L. and J.S.; writing-review and editing, J.L. and W.S.

Funding: This work was supported by the Program for the Philosophy and Social Sciences Research of Higher Learning Institutions of Shanxi (PSSR: 2017336) and Taiyuan University of Science and Technology Scientific Research Initial Funding (TYUST SRIF No. W20182014 and No. W20192003).

Acknowledgments: The authors thank the anonymous reviewers and all the editors in the process of manuscript revision.

Conflicts of Interest: The authors declare no conflicts of interest.

\section{References}

1. Chen, J.; Huang, J.; Zheng, L.; Zhang, C. An Empirical Analysis of Telecommunication Infrastructure Promoting the Scale of International Service Trade: Based on the Panel Data of Countries along the Belt and Road. Transform. Bus. Econ. 2019, 18, 124-139.

2. Thomas, S.D. Electricity industry reforms in smaller European countries and the Nordic experience. Energy 2006, 31, 788-801. [CrossRef]

3. Stjepcevic, J.; Siksnelyte, I. Corporate Social Responsibility in Energy Sector. Transform. Bus. Econ. 2017, 16, 21-33.

4. Pollitt, M.G. The role of policy in energy transitions: Lessons from the energy liberalization era. Energy Policy 2012, 50, 128-137. [CrossRef]

5. Brożyna, J.; Mentel, G.; Szetela, B. Renewable energy and economic development in the European Union. Acta Polytech. Hung. 2017, 14, 11-34.

6. Streimikiene, D.; Simanaviciene, Z.; Kovaliov, R. Corporate social responsibility for implementation of sustainable energy development in Baltic States. Renew. Sustain. Energy Rev. 2009, 13, 813-824. [CrossRef]

7. Sartori, S.; Witjesb, S.; Campos, L.M.S. Sustainability performance for Brazilian electricity power industry: An assessment integrating social, economic and environmental issues. Energy Policy 2017, 111, 41-51. [CrossRef]

8. Camargos, M.R.; Jannuzzi, G.M.; Gavira, M.O. Analysis of the sustainability reporting initiatives of electric utilities in Brazil. Industrija 2014, 42, 127-147. [CrossRef]

9. Szczepankiewicz, E.I.; Mucko, P. CSR Reporting Practices pf Polish Energy and Mining Companies. Sustainability 2016, 8, 126. [CrossRef]

10. Sidhoum, A.A.; Serra, T. Corporate Social Responsibility and Dimensions of Performance: An Application to U.S. Electric Utilities. Util. Policy 2017, 48, 1-11. [CrossRef] 
11. Kraft, B. Shedding Light on Stakeholder Power in a Regulated Market: A Study of Variation in Electric Utilities' Climate Change Disclosures. Organ. Environ. 2018, 31, 314-338. [CrossRef]

12. Chang, K. The effects of ownership and capital structure on environmental information disclosure: Empirical evidence from Chinese listed electric firms. WSEAS Trans. Syst. 2013, 12, 315-330.

13. Li, J.; Sun, X.; Li, G. Relationships among Green Brand, Brand Equity and Firm Performance: Empirical Evidence from China. Transform. Bus. Econ. 2018, 17, 221-236.

14. Bahari, N.A.S.; Alrazi, B.; Husin, N.M. A comparative analysis of carbon reporting by electric generating companies in China, India, and Japan. Proc. Econ. Financ. 2016, 35, 74-81. [CrossRef]

15. Alrazi, B.; Villiers, C.D.; Staden, C.J.V. The environmental reporting of electric utilities: An international comparison. In Proceedings of the 9th CSEAR Australasian Conference, Albury Wodonga, Australia, 5-7 December 2010.

16. Traxler, A.A.; Greiling, D. Sustainable public value reporting of electric utilities. Balt. J. Manag. 2019, 14, 103-121. [CrossRef]

17. Talbot, D.; Boiral, O. GHG reporting and impression management: An assessment of sustainability reports from the energy sector. J. Bus. Ethics 2018, 147, 367-383. [CrossRef]

18. Zhao, W. Corporate Social Responsibility in the Energy Industry: A Content Analysis of Leading Energy Companies' Websites. Available online: http://www.diginole.lib.fsu.edu/islandora/object/fsu: 253157/datastream/PDF/view (accessed on 28 March 2019).

19. Rimsaite, L. Corruption risk mitigation in energy sector: Issues and challenges. Energy Policy 2019, 125, 260-266. [CrossRef]

20. Spence, D.B. Corporate social responsibility in the oil and gas industry: The importance of reputational risk. Chi.-Kent L. Rev. 2011, 86, 59-85.

21. Gennaioli, C.; Tavoni, M. Clean or dirty energy: Evidence of corruption in the renewable energy sector. Public Choice 2016, 166, 261-290. [CrossRef]

22. Krishnamurti, C.; Shams, S.; Velayutham, E. Corporate social responsibility and corruption risk: A global perspective. J. Contemp. Account. Econ. 2018, 14, 1-21. [CrossRef]

23. Greiling, D.; Traxler, A.A.; Stötzer, S. Sustainability reporting in the Austrian, German and Swiss public sector. Int. J. Public Sect. Manag. 2015, 28, 404-428. [CrossRef]

24. Meynhardt, T.; Gomez, P.; Schweizer, M.T. The public value scorecard: What makes an organization valuable to society? Performance 2014, 6, 1-8.

25. Dumay, J.; Guthrie, J.; Farneti, F. GRI sustainability reporting: Guidelines for public and third sector organizations. Public Manag. Rev. 2010, 12, 531-548. [CrossRef]

26. Bozeman, B.; Johnson, J. The political economy of public values: A case for the public sphere and progressive opportunity. Public Manag. Rev. 2015, 45, 61-85. [CrossRef]

27. Rentsch, C.; Finger, M. Yes, no, maybe: The ambiguous relationship between state-owned enterprises and the state. Ann. Public Coop. Econ. 2015, 86, 617-640. [CrossRef]

28. Cantele, S.; Tsalis, T.A.; Nikolaou, L.E. A New Framework for Assessing the Sustainability Reporting Disclosure of Water Utilities. Sustainability 2018, 10, 433. [CrossRef]

29. Mio, C. Corporate social reporting in Italian multi-utility companies: An empirical analysis. Corp. Soc. Responsib. Environ. Manag. 2010, 17, 247-271. [CrossRef]

30. Schwedler, M.V. CSR in the UK Water Industry: 'Doing the Right Thing'? A Case Study. Soc. Environ. Account. J. 2011, 31, 125-137. [CrossRef]

31. Larrinaga-Gonzélez, C.; Pérez-Chamorro, V. Sustainability accounting and accountability in public water companies. Public Money Manag. 2008, 28, 337-343. [CrossRef]

32. Palme, U.; Tillman, A.M. Sustainable development indicators: How are they used in Swedish water utilities? J. Clean. Prod. 2008, 16, 1346-1357. [CrossRef]

33. Linneman, M.H.; Hoekstra, A.Y.; Berkhout, W. Ranking water transparency of Dutch Stock-listed companies. Sustainability 2015, 7, 4341-4359. [CrossRef]

34. Kleinman, G.; Kuei, C.H.; Lee, P. Using formal concept analysis to examine water disclosure in corporate social responsibility reports. Corp. Soc. Responsib. Environ. Manag. 2017, 24, 341-356.

35. Lambooy, T. Corporate social responsibility: Sustainable water use. J. Clean. Prod. 2011, 19, 852-866. [CrossRef] 
36. Dupire, M.; M'Zali, B. CSR Strategies in Response to Competitive Pressures. J. Bus. Ethics 2018, 148, $603-623$. [CrossRef]

37. Runhaar, H.; Lafferty, H. Governing Corporate Social Responsibility: An Assessment of the Contribution of the UN Global Compact to CSR Strategies in the Telecommunications Industry. J. Bus. Ethics 2009, 84, 479-495. [CrossRef]

38. Mapelli, F.; Arena, M.; Azzone, G. What Drivers Determine CSR Strategies in the Energy Industry? Evidence from Italy. In Proceedings of the European Conference on Sustainability, Energy \& the Environment 2016, Brighton, UK, 7-10 July 2016.

39. Lu, J.; Ren, L.; Lin, W.; He, Y.; Streimikis, J. Policies to promote Corporate social responsibility (CSR) and assessment of CSR impacts. EM Ekon. Manag. 2019, 22, 82-98. [CrossRef]

40. Lu, J.; Ren, L.; He, Y.; Lin, W.; Streimikis, J. Linking Corporate Social Responsibility with Reputation and Brand of the Firm. Amfiteatru Econ. 2019, 21, 442-460.

41. Lu, J.; Ren, L.; Qiao, J.; Lin, W.; He, Y. Female Executives and Corporate Social Responsibility Performance: A Dual Perspective of Differences in Institutional Environment and Heterogeneity of Foreign Experience. Transform. Bus. Econ. 2019, 18, 174-196.

42. Mezher, T.; Tabbara, S.; Al-Hosany, N. An overview of CSR in the renewable energy sector Examples from the Masdar Initiative in Abu Dhabi. Manag. Environ. Qual. 2010, 21, 744-760. [CrossRef]

43. Stanisavljević, M. Does Customer Loyalty Depend on Corporate Social Responsibility. J. Contemp. Issues Econ. Bus. 2017, 63, 38-46. [CrossRef]

44. Yuen, K.F.; Thai, V.V.; Wong, Y.D. Are customers willing to pay for corporate social responsibility? A study of individual-specific mediators. Total Qual. Manag. Bus. Excell. 2016, 27, 912-926. [CrossRef]

45. Romani, S.; Grappi, S.; Bagozzi, R.P. Corporate socially responsible initiatives and their effects on consumption of green products. J. Bus. Ethics 2016, 135, 253-264. [CrossRef]

46. Abbas, M.; Gao, Y.; Shah, S. CSR and Customer Outcomes: The Mediating Role of Customer Engagement. Sustainability 2018, 10, 4243. [CrossRef]

47. Öberseder, M.; Schlegelmilch, B.B.; Murphy, P.E. CSR practices and consumer perceptions. J. Bus. Res. 2013, 66, 1839-1851. [CrossRef]

48. Öberseder, M.; Schlegelmilch, B.B.; Murphy, P.E.; Gruber, V. Consumers' Perceptions of Corporate Social Responsibility: Scale Development and Validation. J. Bus. Ethics 2014, 124, 101-115. [CrossRef]

49. Vlachos, P.A.; Tsamakos, A.; Vrechopoulos, A.P.; Avramidis, P.K. Corporate social responsibility: Attributions, loyalty, and the mediating role of trust. J. Acad. Mark. Sci. 2009, 37, 170-180. [CrossRef]

50. Li, J.; Zhang, F.; Sun, S. Building Consumer-Oriented CSR Differentiation Strategy. Sustainability 2019, 11, 664. [CrossRef]

51. Yoo, D.; Lee, J. The Effects of Corporate Social Responsibility (CSR) Fit and CSR Consistency on Company Evaluation: The Role of CSR Support. Sustainability 2018, 10, 2956. [CrossRef]

52. Comyns, B.; Figge, F. Greenhouse gas reporting quality in the oil and gas industry. Account. Audit Account. 2015, 28, 403-433. [CrossRef]

53. Przepoirka, W.; Horne, C. How Can Consumer Trust in Energy Utilities be Increased? The Effectiveness of Prosocial, Pro-environmental, and Service-oriented Investments as Signals of Trustworthiness. Available online: https://journals.sagepub.com/doi/full/10.1177/1086026618803729 (accessed on 15 April 2019).

54. Kotler, P.; Keller, K.L. Marketing Management, 11th ed.; Prentice Hall: Upper Saddle River, NJ, USA, 2003; ISBN 0-13-145757-8658.

55. Reed, D.J. Green Stakeholder Value: Hype or Hit? Environ. Qual. Manag. 1999, 9, $43-47$.

56. Dal Bo, E.; Rossi, M.A. Corruption and inefficiency: Theory and evidence from electric utilities. J. Public Econ. 2007, 91, 939-962. [CrossRef]

57. Tregidga, H.; Milne, M.J. From sustainable management to sustainable development: A longitudinal analysis of a leading New Zealand environmental reporter. Bus. Strateg. Environ. 2006, 15, 219-241. [CrossRef]

58. Du, S.; Vieira, E.T., Jr. Striving for Legitimacy Through Corporate Social Responsibility: Insights from Oil Companies. J. Bus. Ethics 2012, 110, 413-427. [CrossRef]

59. Guenther, E.; Hoppe, H.; Poser, C. Environmental Corporate Social Responsibility of Firms in the Mining and Oil and Gas Industries: Current Status Quo of Reporting Following GRI Guidelines. Available online: https://www.jstor.org/stable/greemanainte.53.7 (accessed on 28 April 2019). 
60. Vasi, I.B.; King, B.G. Social movements, risk perceptions, and economic outcomes: The effect of primary and secondary stakeholder activism on firms' perceived environmental risk and financial performance. Am. Sociol. Assoc. 2012, 77, 573-596. [CrossRef]

61. Short, J.L.; Toffel, M.W. Making self-regulation more than merely symbolic: The critical role of the legal environment. Adm. Sci. Q. 2010, 55, 361-396. [CrossRef]

62. International Atomic Energy Agency. Energy Indicators for Sustainable Development: Guidelines and Methodologies. Available online: http://www.unosd.org/content/documents/1237Pub1222_web\%20EISD.pdf (accessed on 1 June 2018).

63. Zheng, X.; Štreimikienè, D.; Baležentis, T.; Mardani, A.; Cavallaro, F.; Liao, H. A review of greenhouse gas emission profiles, dynamics, and climate change mitigation efforts across the key climate change players. $J$. Clean Prod. 2019, 234, 1113-1133. [CrossRef]

64. European Commission. Member State Progress Reports under Directive 2009/28/EC. Available online: https://ec.europa.eu/energy/en/topics/renewable-energy/progress-reports (accessed on 3 June 2019).

65. European Commission. 2018 Assessment of the Progress Made by Member States towards the National Energy Efficiency Targets for 2020 and towards the Implementation of the Energy Efficiency Directive as Required by Article 24(3) of the Energy Efficiency Directive 2012/27/EU. Available online: https://ec.europa.eu/commission/sites/beta-political/files/report-2018-assessment-progress-energyefficiency-targets-april2019_en.pdf (accessed on 8 June 2019).

66. European Environment Agency. Trends and projections in Europe 2018, Tracking Progress towards Europe's Climate and Energy Targets. Available online: https://www.eea.europa.eu//publications/trendsand-projections-in-europe-2018-climate-and-energy (accessed on 11 June 2019).

67. Bryson, J.M.; Crosby, B.C.; Bloomberg, L. Public value governance: Moving beyond traditional public administration and the New Public Management. Public Adm. Rev. 2014, 74, 445-456. [CrossRef]

68. Jenkins, H.; Yakovleva, N. Corporate Social Responsibility in the Mining Industry: Exploring Trends in Social and Environmental Disclosure. J. Clean. Prod. 2006, 14, 271-284. [CrossRef]

69. Kolk, A.; Lindeque, J.; Buuse, D.V.D. Regionalization strategies of EU electric utilities. Brit. J. Manag. 2014, 25, 77-99. [CrossRef]

70. Kudłak, R.; Szőcsb, I.; Krumay, B.; Martinuzzi, A. The future of CSR-Selected findings from a Europe-wide Delphi study. J. Clean. Prod. 2018, 25, S77-S99. [CrossRef]

71. Danilet, M.; Mihai, O. CSR Online Discourse Practices in the Romanian Energy Sector. J. East. Eur. Res. Bus. Econ. 2013, 2013, 1-9. [CrossRef]

72. Latvenergo. Sustainability and Annual Report. 2018. Available online: https://www.latvenergo.lv/files/news/ LE_sustainability_annual_report_2018.pdf (accessed on 15 June 2019).

73. Lietuvos Energija. Corporate Sustainability Report 2018. Available online: https://www.le.lt/index.php/ about-us/reports/432 (accessed on 16 June 2019).

74. Eesti Energia. Annual Report 2018. Available online: https://www.energia.ee/-/doc/8457332/ettevottest/ aastaaruanne2018/EE_Annual_report_2018.pdf (accessed on 19 June 2019).

(C) 2019 by the authors. Licensee MDPI, Basel, Switzerland. This article is an open access article distributed under the terms and conditions of the Creative Commons Attribution (CC BY) license (http://creativecommons.org/licenses/by/4.0/). 